\title{
1 Environmental management zoning of coal-fired power plants in China in the
}

2 context of carbon neutrality

3 Wen Qiu, Mingxuan Zhao, Lianhong Lv*, Hong Luo

4 Chinese Research Academy of Environmental Sciences, Beijing, 100012, China

5 Abstract: The total amount of greenhouse gas emissions directly or indirectly generated by thermal power enterprises at any given time can be offset through afforestation, energy conservation and emission reduction. The present situation and control methods of $\mathrm{CO}_{2}$ emission in China's coal-fired thermal power industry are introduced. The complex ecosystem is a unity of ecological functions composed of human society, economic activities and natural conditions. In the context of carbon neutrality and based on the theory of composite ecosystem, this paper divides the coal-fired thermal power plants in China into environmental management zones, calculates the atmospheric environmental capacity, and puts forward the concept of regional atmospheric environmental capacity, classification and zoning control. Finally, the management and control units are classified, and differentiated management and control requirements are put forward to provide a reference for regional air quality standard planning.

Keywords: Composite ecosystem; Carbon neutralization; Coal-fired power; Environmental management zoning; Coordination and control

About the author: Wen Qiu, qqqiuwen@163.com; Mingxuan Zhao, kjnjxx@163.com; Hong Luo, luohong@craes.org.cn

*Responsible Author: Lianhong Lv, lvlh@craes.org.cn

\section{Introduction}

Energy is the material basis of social development, while the environment is the carrier of energy and also the living space for all kinds of organisms [1-2]. China's long-term and current energy consumption structure are dominated by coal. At present, the proportion of coal consumption in China is as high as 68\% [3-4]. However, with the accelerating process of 
industrialization and the rapid development of the economy, the unreasonable development and use of coal and other natural resources for energy, and the arbitrary emission of $\mathrm{CO}_{2}, \mathrm{SO}_{2}, \mathrm{NO}_{\mathrm{x}}$ and other pollutants, make the world face severe challenges of resource depletion, the deterioration of the ecological environment, global warming and imbalance of social and economic development [5-7]. Among these severe challenges, gaseous pollutants from coal-fired power and coal-fired processes are one of the main sources of air pollution in China [8-9]. In order to solve these problems, the coordinated development of resources, environment and social economy has attracted the world's attention [10-11]. The historical experience on a global scale shows that energy, environment and economy form a complex organic unity. Seeking the coordinated development of energy, economy, and environment subsystem is not only the most essential requirement of sustainable development theory but also an effective way to realize the sustainable, steady and high-speed development of a national economy.

Tansley, a British scholar, first proposed the concept of an ecosystem. He believed that an ecosystem is a unity composed of a biological community and a natural environment [12]. Professor Ma Shijun, a famous ecologist and environmental scientist in China, first put forward the theory of complex ecosystem in 1981. He said that the complex ecosystem includes three subsystems, namely, society, economy and nature [13-14]. He pointed out that the society, economy and nature in which human beings live and produce is indeed an inseparable complex system. Society is the superstructure of the economy, while the economy supports the society and also serves as a bridge between society and nature. On the other hand, nature supports the whole human society and the economy, and exists as a basic situation in the complex ecosystem.

The theory of a complex ecosystem can better explain the current energy and environmental problems in the region [15-16]. The regional complex ecosystem can be divided into two parts: the human system and the natural system. The human system is composed of both social and economic systems. Rapid economic growth and social development often come at the expense of the regional ecological environment, leading to the imbalance and damage of the regional complex ecosystem. 
53 The damaged regional natural system, in turn, affects the economic and social development of the 54 region. Compound ecosystem management refers to the process of applying ecological, scientific and sustainable methods to carry out adaptive management of local affairs on the basis of a full understanding of the relationship among social, economic and natural systems within a certain space [17-18]. The ultimate goal of composite ecosystem management is to make the overall structure of the composite ecosystem stable. In such a stable composite ecosystem, the subsystems coexist harmoniously and promote each other, thereby guaranteeing the coordinated and efficient operation of the whole composite ecosystem.

Many scholars in China and beyond have studied the theory and method of regional energy environment complex ecosystem regulation in China. Wang Rusong et al. [19] pointed out that cities and regions of China are a kind of a social economic natural complex ecosystem. Studying the dynamic mechanism and cybernetic method of the complex ecosystem as well as creating a demonstration model of planning, construction and management of the complex ecosystem at different scales can provide a reference for the implementation of the scientific outlook on development, the promotion of a circular economy, the promotion of sustainable development and the promotion of sustainable development. Scientific methods and decision support are provided for the construction of a harmonious society and healthy environment. On the basis of analyzing the characteristics of the coordinated energy environment economy complex system, Lianhong et al. [20] established the analysis model of the coordination of China's energy environment economy complex system and put forward the corresponding control measures. The results show that in the past 15 years, the "energy environment economy" complex system in China is slowly evolving towards coordination. Suresh et al. [21] analyzed the energy, exergy, environment, economy and other factors of a coal-fired power plant to determine their technical and economic feasibility. Their research showed that under the "fuel-saving mode" operation of a steam turbine, by replacing all the exhaust steam with a feedwater heater, the coal consumption of a coal-fired power plant can be instantly reduced by about $14-19 \%$. Also, the authors found that based on exergy rather than energy, 
79

80

81

solar energy was more effective for water heating and that using the best possible solar-assisted feed water heating scheme can reduce $\mathrm{CO}_{2}$ emissions from coal-fired power plants. Nevertheless, there are few studies on the application of composite ecosystem to energy-environment by far, especially the energy-environment management and control of thermal power enterprises, and there are few literature reports. Against the backdrop of carbon neutrality, the work applies the "complex ecosystem theory" to the zoning of environmental management and control of coal-fired power plants, calculates the atmospheric environmental capacity, and puts forward the concept of regional atmospheric environmental capacity, classification and zoning management and control. Lastly, the study divides the environmental management and control of coal-fired thermal power plants in China by combining qualitative analysis with quantitative analysis and puts forward differentiated management and control requirements so as to provide a reference for regional air quality standard planning. The research results can be utilized to explore a new set of coal-fired thermal power environmental management and control theory and method system.

\section{Research methods}

\subsection{Research progress of complex ecosystem theory}

1) Energy-economic-environment-ecology complex ecosystem and sustainable development

The economy energy environment (3e) system is a complex system that includes three subsystems of economy, energy and environment[22-23]. Each of these subsystems is closely related to each other. At the same time, there are also mutual communications, mutual influences and mutual stimulations among economy, energy and environment both inside and outside of the region [24-25]. In the process of the interaction of the three subsystems, the economic system plays the role of intermediary, controller and coordinator.

The evaluation of the coordinated development of the economy and environment is one of the hot issues in the study of sustainable development in developing countries. At present, the research on the coordinated development evaluation of the economic environment composite ecosystem has 
105 gradually changed from qualitative and static analyses to quantitative and dynamic trend evaluations. There are many evaluation models, but the main ones include the input-output model [26], EKC measurement model [27], grey system model [28], and comprehensive evaluation model of coordinated scheduling and coordinated development degree [29]. Each of these models has its advantages, disadvantages and application scope, which determine the research progress in this field to a certain extent.

2) Evaluation index system of coordinated development

A composite system is an open, nonlinear, dynamic and complex large-scale system, which involves many objectives and is easily affected by external factors. Different factors also directly affect the results of empirical analysis. According to the above analysis of game and coordination of economic and environmental development, the state or degree of system coordination can be reflected by mathematical models or quantitative methods. In this paper, a comprehensive evaluation index system of the economy and environment composite system is established to realize this process, as shown in Table1. Based on the principles of comprehensiveness, representativeness, quantification, operability and scientificalness, the evaluation index system of energy environment composite system was constructed by selecting appropriate indexes.

3) Analysis on coordination degree of compound ecosystem

It is necessary to use coordination degree to calculate coordination degree among multiple systems so as to evaluate coordinated development. Coordination degree is a measure of the degree of harmony between the system or the internal elements of the system in the development process, reflecting the trend of the system from disorder to order. It is a quantitative indicator of the coordination of energy, economy, environment and ecosystem. By referring to the capacity coupling coefficient model in physics, the coupling coordination degree model between composite ecosystems was constructed. Then, the coupling degree between the energy system, economic system, environmental system and economic system was calculated as follows: 
130

$$
\mathrm{C}=4\left[\frac{\mathrm{U}_{1} \times \mathrm{U}_{2} \times \mathrm{U}_{3} \times \mathrm{U}_{4}}{\left(\mathrm{U}_{1}+\mathrm{U}_{2}+\mathrm{U}_{3}+\mathrm{U}_{4}\right)^{4}}\right]^{\frac{1}{4}}
$$

where, $C$ is the coupling degree, and $\mathrm{U}_{1}, \mathrm{U}_{2}, \mathrm{U}_{3}$, and $\mathrm{U}_{4}$ are the development indexes for each subsystem (energy, economic, environmental and ecological subsystem respectively).

In order to avoid the pseudo coordination evaluation results and reflect the actual development level of each system and the contribution to the system order degree, the coupling coordination degree coefficient is defined on the basis of the reference coupling degree. The formula for calculating the comprehensive coupling coordination degree of the energy, economy, environment and ecosystem systems were as follows:

$$
\begin{gathered}
D=\sqrt{C T} \\
T=\alpha f_{1}+\beta f_{2}+\gamma f_{3}+\theta f_{4}
\end{gathered}
$$

Where $\mathrm{D}$ is the coupling coordination coefficient; $\mathrm{C}$ is the coupling degree; $\mathrm{T}$ is the comprehensive development index; $\alpha, \beta, \gamma, \theta$. It is considered that energy, economy, environment and ecosystem are equally important, all of which are taken as 0.25 . The size of the coordination coefficient indicates the degree of coordination between systems, and different intervals of coordination coefficient can be used as the measurement standard of different coordination degrees. The research on the coordination degree of the composite ecosystem provides theoretical and application basis for the environmental management and control of thermal power coal-fired power plants in China.

\subsection{Estimation of atmospheric environmental capacity}

Atmospheric environmental capacity refers to the maximum load of pollutants in an environment on the premise that human survival and development are not harmed, and the balance of the natural ecosystem is not damaged [30-31]. Many accounting methods have been proposed by scholars at home and abroad. A-P value method is one of the important methods for estimating atmospheric environmental capacity, which has been widely used in the current air pollution 
154 prevention and control work [32-33]. In this study, A-P value method was used to calculate the

155 atmospheric environmental capacity of each control unit [34-35]. According to the estimation

156 results of atmospheric environmental capacity, the environmental management of coal-fired power

157 plants in China was divided into different zones, and the differentiated management and control

158 requirements are put forward. The formula for calculating atmospheric environmental capacity is as

159 follows:

160

$$
\mathrm{Q}=\mathrm{A}\left(\mathrm{C}_{\mathrm{s}}-\mathrm{C}_{\mathrm{b}}\right) \sqrt{\mathrm{S}}
$$

161

162

163

164

165

Where: $\mathrm{Q}$ is the annual allowable total emission limit of pollutants, (i.e., the ideal atmospheric capacity), $10^{4} \mathrm{t} / \mathrm{a}$; $\mathrm{A}$ is the total amount control coefficient of geographical region, $10^{4} \mathrm{~km}^{2} / \mathrm{a}$; $\mathrm{S}$ is the total area of the control area, $\mathrm{km}^{2} ; \mathrm{C}_{\mathrm{s}}$ is the annual average concentration limit of a pollutant corresponding to each province, $\mathrm{mg} / \mathrm{m}^{3}$; and $\mathrm{C}_{\mathrm{b}}$ is the local concentration in the control area, $\mathrm{mg} / \mathrm{m}^{3}$.

\section{Results and analyses}

3.1. $\mathrm{CO}_{2}$ emission status and control methods of coal-fired thermal power industry

Research shows that China will reach a peak $\mathrm{CO}_{2}$ emission of 10.6 billion tons around 2027 [36]. However, at present, China's coal-fired thermal power industry has no relevant statistical data on carbon dioxide emissions, so it can only be estimated from the coal consumption, fuel emission factor, the average low-temperature calorific value of fuel, carbon oxidation rate and data on other relevant parameters [37]. Through afforestation, energy conservation and emission reduction, the carbon dioxide or greenhouse gas emissions directly or indirectly generated by thermal power enterprises in a certain period of time can be offset. With the rapid development of China's economy and society, and the acceleration of coal electricity integration construction, $\mathrm{CO}_{2}$ emissions will gradually increase. In China, the control methods of carbon dioxide in thermal power industries are mainly management methods, such as shutting down small thermal power units, reducing the power consumption rate of power plants, and the collaborative reduction of carbon dioxide by sulfur 
179 dioxide emission reduction. These $\mathrm{CO}_{2}$ control methods are adopted given that China's carbon

180 dioxide emission reduction technology is still at the stage of research and project demonstration,

181 including pre-combustion capture and post-combustion capture.

182

\subsection{Coordination degree analysis of complex ecosystem}

Coordination degree is a measure of the degree of harmony between the system or the internal elements of the system in the development process. It reflects the trend of the system from disorder to order. Furthermore, coordination degree is a quantitative indicator of the coordination of energy, economy, environment and ecosystem. By referring to the capacity coupling coefficient model in physics, the coupling coordination degree formula of China's energy, economic, environmental and ecological composite ecosystem was constructed. The results are presented in Table 2 . As shown in Table2, Item 1 to Item 21 refer to different provinces/citis/districts. Unfortunately, there are not too many data can be calculated through SPSS19.0 software. The larger the C value of coupling degree in different regions, the greater the interaction between the systems. Similarly, the larger the D value of coupling coordination degree, the higher the coordination degree. As can be seen from Table 2, the coupling coordination degree of the energy economic environmental ecology composite ecosystem in most provinces in China is low, and most of them are low-quality coordination. This shows that it is urgent to adjust the energy structure, strictly control the total amount of coal consumption, strengthen the clean utilization of coal, expand natural gas utilization to apply the composite ecosystem to the environmental management and control of coal-fired power plants, implement the scientific outlook on development, promote a circular economy, and properly manage the ecological environment.

\subsection{Analysis of atmospheric environmental capacity}

In this study, the A-value of each province in China was obtained by referring to the manual of the total amount control method of urban air pollutants. The minimum A-value of each province was taken as the national recommended value to determine the total amount of air pollutants in each 
204 province. It is assumed that the first-class standard limit of pollutants in the ambient air quality 205 standard (GB3095-2012) is taken as the air quality standard. Going by this air quality standard, the annual concentration limit of $\mathrm{SO}_{2}$ in each province is $0.02 \mathrm{mg} / \mathrm{m}^{3}$. The estimated atmospheric environmental capacity for each province in China is presented in Table 3. In this paper, atmospheric environmental capacity intensity is classified into high, medium, and low according to $20 \sim 5$ million tons, $5 \sim 1$ million tons and $0 \sim 1$ million tons, respectively.

3.4 Stability of atmospheric environment zoning

1) The thesis fully considers the theories and concepts of atmospheric environmental capacity, puts forward an evaluation method of atmospheric environmental capacity and conducts case studies, which can effectively analyze and evaluate the atmospheric environmental capacity of the regional ecological environment.

2) Cointegration test between atmospheric carrying capacity and economic development

In order to examine the stability of the atmospheric environment zoning over time, Spss19 statistical analysis software to test the above 26 evaluation factors by ADF inspection.The results (shown in Table 4) show that under the original hypothesis, the value of the unit root t-test statistic is higher than the corresponding DW critical value at three significance levels $(1 \%, 5 \%$ and $10 \%)$. Therefore, our initial hypothesis was confirmed, indicating that the initial data set was dynamic, that there is unit root, and the data need to be stabilized. After the first-order difference, the significance level of $5 \%$, and the critical value of unit root test was lower than the corresponding DW critical value. The original hypothesis was thus rejected, indicating that the data in the original data set was stable after the first-order difference, and the stability test was completed.

3) Model identification and fitting

We used spss19 statistical analysis software to built a ARIMA (P, D, q) model to predict China's atmospheric carrying capacity. The results (illustrated in Table 5) showed that the ARIMA model requires the model residual to be white noise, that is, no autocorrelation. The model basically meets the prediction requirements of atmospheric carrying capacity in China. Predicted by ADF test 
230 and ARIMA (P, D, q) model show that the energy, economy, environment and ecosystem complex

231 ecosystem in most parts of China were stable.

3.5. Coal-fired thermal power area division and control requirements

In order to evaluate the impact of coal-fired power plants on regional atmospheric environment in China, based on the theory of complex ecosystem, this paper preliminarily divides the types of coal-fired power plants in China into environmental management categories, analyzes the atmospheric environmental capacity, and puts forward the requirements and suggestions for the differentiated environmental management of different types of control areas of atmospheric environmental capacity. The results are presented in Table 6. Inner Mongolia, Heilongjiang, Xinjiang and some other places have relatively large atmospheric environmental capacity and abundant coal resources (Table 6). Therefore, the establishment of modern large-scale coal power bases focusing on power transmission and capable of producing up to 10 million kilowatts of energy should be undertaken. Liaoning, Jilin and some other places still have certain environmental capacities, and the emission of air pollutants from new power plants must be regulated to meet the standards of gas-fired power plants. Beijing, Shanghai, Chongqing and Tianjin have no environmental capacities; therefore, new coal-fired power units should be prohibited.

\section{Conclusions and suggestions}

China's energy and environment vary greatly in time and space, and the constraints of the energy industry are different. The environmental protection type of thermal power plants energy industry include the existing zoning, the restrictive factors and spatial distribution of existing enterprise are sufficiently taken into account by researchers. Based on the complex ecosystem theory, this paper divided the environmental management area of coal-fired power plants in China, 253 which is conducive to the implementation of "adjusting measures to local conditions", " development of dislocation", "classified management" and "zoning and management" in the field of 
255 thermal power generation. Differentiated management and control requirements are put forward to 256 provide a reference for regional air quality standard planning. The zoning environmental policy is 257 advantageous to the benign development of thermal power industry. According to the types of atmospheric environmental capacity in different areas of China, a new set of theories and methods for environmental management of coal-fired thermal power plants were explored. It is suggested that the prevention and control of environmental pollution should be carried out according to the goal of "taking improving environmental quality as the core". The following conclusions and suggestions are drawn from the environmental management of coal-fired power plants in China:

1) Considering the impact of coal-fired thermal power on the regional atmosphere, it is suggested that the layout of coal-fired thermal power in China should be appropriately adjusted according to the development situation of different regions to organize and coordinate the coordinated development of energy, environment, economy and ecology.

2) With the rapid development of economics, sustainable development has increasingly become the ideal goal of development and environmental management, and the measurement, environmental management, and the coal-fired thermal power environment in China is preliminarily environmental management requirements so as to protect China's ecological environment. qualitative and quantitative evaluation of sustainable development is one of the key issues. In the face of the problems of environmental monitoring and environmental management in sustainable development, a series of development strategies and research countermeasures are put forward.

classified. The result can better coordinate the relationship between humanity and nature and play a good effect in dealing with environmental issues.

4) According to the comprehensive evaluation results of the atmospheric environmental capacity of the study area, aiming at the existing energy and environmental problems in the region, the paper puts forward the strategy of insisting on sustainable development and differentiated

5) The compound ecosystem theory can be applied to the division of coal-fired thermal power 
281 environmental management zones in China, studies and research from the methods and experience

282 of environmental management at home and abroad, especially the energy and environmental 283 management of thermal power enterprises needs to be improved and modified further.

\section{Acknowledgements :}

The research work is financially supported by the Basic Scientific Research Funds in National Nonprofit Institutes, China (No.2019YSKY001).

\section{References:}

[1] Rohse M, Day R, Llewellyn D. Towards an emotional energy geography: Attending to emotions and affects in a former coal mining community in South Wales, UK[J]. Geoforum, 2020, 110: 136-146.

[2] Yan J, Brown M A, Yu D, et al. Policy incentives and social cost of emissions for promoting decentralized energy production: A life cycle cost analysis[J]. Journal of Cleaner Production, 2021, 282(3): 125394.

[3] Chowdhury J I, Hu Y K, Haltasa I, et al. Reducing industrial energy demand in the UK: A review of energy efficiency technologies and energy saving potential in selected sectors, Renewable and Sustainable Energy Reviews, 2018, 94: 1153-1178.

[4] Xu B, Yang M K, Xing B L, et al. Removal of pollutants from aqueous solutions by coals and

302 [5] George A, Shen B X, Kang D R, et al. Emission control strategies of hazardous trace elements 303 from coal-fired power plants in China[J]. Journal of Environmental Sciences, 2020, 93: 66-90.

304 [6] Ma X W, Yang L J, Wu H. Removal of volatile organic compounds from the coal-fired flue gas 305 by adsorption on activated carbon - ScienceDirect[J]. Journal of Cleaner Production, 2021, 302: 
126925.

[7] Chiu C H, Kuo T H, Chang T C, et al. Multipollutant removal of $\mathrm{Hg}^{0} / \mathrm{SO}_{2} / \mathrm{NO}$ from simulated coal-combustion flue gases using metal oxide/mesoporous $\mathrm{SiO}_{2}$ composites[J]. International Journal of Coal Geology, 2017, 170: 60-68.

[8] He K Q, Yuan C G, Jiang Y H, et al. Synergistic effects of Fe-Mn binary oxide for gaseous arsenic removal in flue gas[J]. Ecotoxicology and Environmental Safety, 2021, 207: 111491.

[9] Zhang Y, Wei Y J, Wang C B, et al. Removal of gas-phase arsenic and selenium in flue gas by a new combined spray-and-scattered-bubble technology based on ammonia desulphurization[J]. Science of The Total Environment, 2021, 772: 145622.

[10] Baleta J, Mikulčić H, Klemeš J J, et al. Integration of energy, water and environmental systems for a sustainable development[J]. Journal of Cleaner Production, 2019, 215: 1424-1436.

[11] Zhang S F, Hu T T, Li J b, et al. The effects of energy price, technology, and disaster shocks on China's Energy-Environment-Economy system[J]. Journal of Cleaner Production, 2019, 209: 204-213.

[12] Tansley S A. The effects of energy price, technology, and disaster shocks on China's Energy-Environment-Economy system[J]. Journal of Cleaner Production, 2019, 207: 204-213.

[13] Ma S J. The function of ecological rules in environmental management[J]. Acta scientiae circumstance, 1981, 1(1): 95-100.

[14] Ma S J, Wang R S. The social-economic-Nature complex ecosystem[J]. Acta ecologica sinica, 1984, 4(1): 1-9.

[15] Kuriqi A, Pinheiro A N, Sordo-Ward A, et al. Water-energy-ecosystem nexus: Balancing competing interests at a run-of-river hydropower plant coupling a hydrologic-ecohydraulic approach[J]. Energy Conversion and Management, 2020, 223: 113267.

[16] Zhao Y, Jiang C, Dong X L, et al. Understanding the complex environmental management through a len of food-water-ecosystem nexus: Insights from an ecosystem restoration hotspot in dryland[J]. Science of The Total Environment, 2021, 783: 147029. 
332 [17] Mashizi A K, Sharafatmandrad M. Investigating tradeoffs between supply, use and demand of 333 ecosystem services and their effective drivers for sustainable environmental management[J]. 334 Journal of Environmental Management, 2021, 289: 112534.

335 [18] Ingram R J, Oleson K L, Gove J M. Revealing complex social-ecological interactions through 336 participatory modeling to support ecosystem-based management in Hawai' ${ }^{\circ}[\mathrm{J}]$. Marine Policy, 2018, 337 94: 180-188.

338 [19] Wang R S, Ouyang Z Y. Social-Economic-Natural Complex Ecosystem and Sustainability[J]. 339 Marine Policy, 2018, 94: 180-188.

340 [20] LV L H, Luo H, Zhang Z. Coordination Degree Analysis of the Energy-Environment-Economy 341 Compound System in China[J]. Journal of Beijing Forestry University, 2009, 8(2): 80-83.

342 [21] Suresh M, Reddy K S, Kolar A K. 4-E (Energy, Exergy, Environment, and Economic) analysis 343 of solar thermal aided coal-fired power plants[J]. Energy for Sustainable Development, 2010, 14(4): $344 \quad 267-279$.

345 [22] Wang R S, Li F, Hu D, et al. Understanding eco-complexity: Social-Economic-Natural 346 Complex Ecosystem approach[J]. Ecological Complexity, 2011, 8(1): 15-29.

347 [23] Wang R S, Zhou T, Hu D, et al. Cultivating eco-sustainability: Social-economic-natural 348 complex ecosystem case studies in China[J]. Ecological Complexity, 2011, 8(4): 273-283.

349 [24] Wang Q, Han X Y. Spillover effects of the United States economic slowdown induced by 350 COVID-19 pandemic on energy, economy, and environment in other countries[J]. Environmental $351 \quad$ Research, 2021, 196: 110936.

352 [25] Fazal R, Rehman S A U, Rehman A U, et al. Energy-environment-economy causal nexus in 353 Pakistan: A graph theoretic approach[J]. Energy, 2021, 214: 118934.

354 [26] Ebrahimnejad S, khanbaba A, Samimi S. Development of an Input-Output Model Considering 355 Simultaneous Effect of Risks in Infrastructure under Dynamic Conditions[J]. Reliability 356 Engineering \& System Safety, 2021, 213: 107653.

357 [27] Ulucak R, Bilgili F. A reinvestigation of EKC model by ecological footprint measurement for 
358 high, middle and low income countries[J]. Journal of Cleaner Production, 2018, 188: 144-157.

359 [28] Wang S W, Wang P, Zhang Y F. A prediction method for urban heat supply based on grey 360 system theory[J]. Sustainable Cities and Society, 2020, 52: 101819.

361 [29] Li J S, Sun W, Li M Y, et al. Coupling coordination degree of production, living and

362 ecological spaces and its influencing factors in the Yellow River Basin[J]. Journal of Cleaner Production, 2021, 298: 126803.

[30] Su Y, Yu Y Q. Dynamic early warning of regional atmospheric environmental carrying capacity[J]. Science of The Total Environment, 2020, 714: 136684.

[31] Luo Y J, Li X Y, Cai G T, et al. A study on atmospheric environmental resource accounting: A case of $\mathrm{SO}_{2}$ capacity resources in Chinese provinces[J]. Journal of Environmental Management, 2019, 249: 109432 .

[32] Zhou W Y, Xie Y X, Zhang J, et al. Estimating the remaining atmospheric environmental capacity using a single-box model in a high pollution risk suburb of Chengdu, China[J]. Journal of Environmental Management, 2020, 258: 110052.

[33] Zhou Y J, Zhou J X. Urban atmospheric environmental capacity and atmospheric environmental carrying capacity constrained by GDP-PM2.5[J]. Ecological Indicators, 2017, 73: $637-652$.

[34] Sun M Z, Liu Z B. Study on total quantity control of air pollution in Beixi City[J]. Journal of Safe and Environment, 2011, 11(2): 131-135.

[35] Lin Z J. The application of A-P value method in calculate of urban atmosphere capacity in Quanzhou[J]. Chemical Engineering Equipment, 2013, 5: 224-227.

[36] Cai B F, Li B, Lei Y, et al. China's carbon emission pathway under the carbon neutrality target[J]. China population, resources and environment, 2021, 31(1): 7 -14.

[37] An X H, Jiang J. Status-quo and some suggestions on control of $\mathrm{CO}_{2}$ emission from the thermal power industry of China[J]. China coal, 2011, 5: 108-110. 
Tables

Table 1. Evaluation index system for regulation and control of regional energy and composite

\begin{tabular}{|c|c|c|c|}
\hline Target layer & Subsyste & Criterion layer & Index layer \\
\hline & $\mathbf{m}$ & & \\
\hline $\begin{array}{l}\text { Assessment of } \\
\text { atmospheric } \\
\text { environmental } \\
\text { capacity of } \\
\text { coal-fired }\end{array}$ & \multirow[t]{3}{*}{$\begin{array}{l}\mathrm{A}_{1} \text { : energy } \\
\text { subsystem }\end{array}$} & Energy production & $\begin{array}{l}\mathrm{C}_{11}: \text { per capita energy } \\
\text { production/T standard coal } \\
\mathrm{C}_{12}: \text { raw coal output per capita/T } \\
\mathrm{C}_{13}: \text { power generation per } \\
\text { capita/(kWh) }\end{array}$ \\
\hline $\begin{array}{l}\text { thermal power } \\
\text { plants in China } \\
\text { under the } \\
\text { background of }\end{array}$ & & $\begin{array}{c}\text { Energy } \\
\text { consumption }\end{array}$ & $\begin{array}{l}\mathrm{C}_{14}: \text { per capita energy } \\
\text { consumption } / \mathrm{T} \\
\mathrm{C}_{15}: \text { elasticity coefficient of } \\
\text { energy consumption } / \%\end{array}$ \\
\hline \multirow[t]{4}{*}{ index system } & & Energy utilization & $\begin{array}{l}\mathrm{C}_{16}: 10000 \text { yuan GDP energy } \\
\text { consumption/T } \mathrm{T} \\
\text { coal/10000 yuan } \\
\mathrm{C}_{17}: \text { energy processing and } \\
\text { conversion efficiency } / \%\end{array}$ \\
\hline & \multirow{3}{*}{$\begin{array}{c}\text { A } \mathrm{A}_{2}: \\
\text { economic } \\
\text { subsystem }\end{array}$} & Economic scale & $\mathrm{C}_{21}:$ per capita GDP/yuan \\
\hline & & Economic structure & $\begin{array}{l}\mathrm{C}_{22}: \text { proportion of tertiary industry } \\
\text { in } \mathrm{GDP} / \%\end{array}$ \\
\hline & & Economic growth & $\mathrm{C}_{23}$ : GDP growth rate $/ \%$ \\
\hline
\end{tabular}




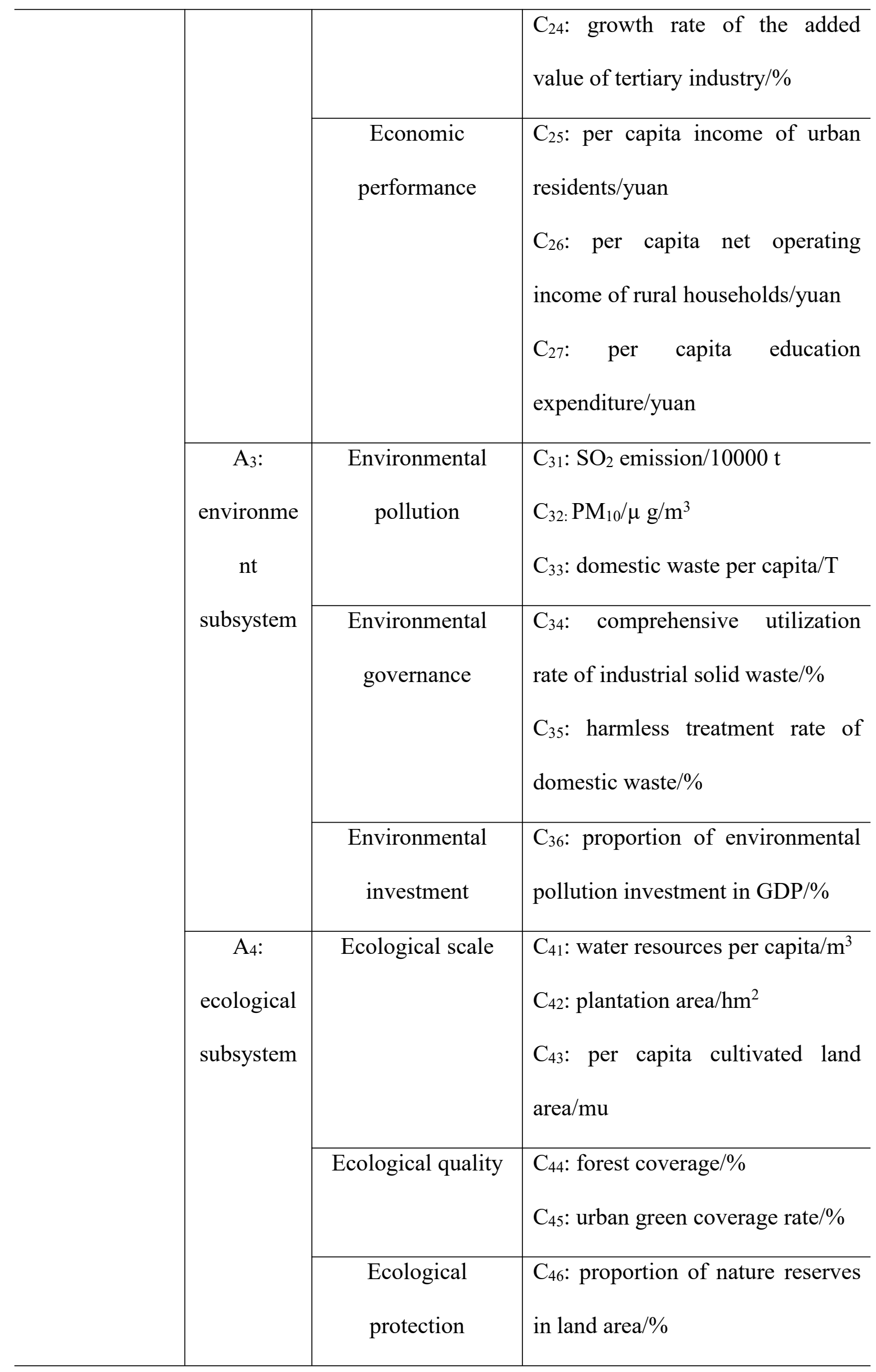


Table 2. Calculated coupling coordination degree of different regions

\begin{tabular}{|c|c|c|c|c|c|}
\hline Term & $\begin{array}{c}\text { C value } \\
\text { of } \\
\text { coupling } \\
\text { degree }\end{array}$ & \begin{tabular}{|c|} 
Coordination \\
index $\mathbf{T}$ \\
value
\end{tabular} & $\begin{array}{c}\text { D value of } \\
\text { coupling } \\
\text { coordination } \\
\text { degree }\end{array}$ & $\begin{array}{c}\text { Coordination } \\
\text { level }\end{array}$ & $\begin{array}{c}\text { Coupling } \\
\text { coordination } \\
\text { degree }\end{array}$ \\
\hline Item 1 & 1 & 0.01 & 0.1 & 2 & $\begin{array}{c}\text { Severe } \\
\text { imbalance }\end{array}$ \\
\hline Item 2 & 1 & 0.01 & 0.1 & 2 & $\begin{array}{c}\text { Severe } \\
\text { imbalance }\end{array}$ \\
\hline Item 3 & 1 & 0.01 & 0.1 & 2 & $\begin{array}{c}\text { Severe } \\
\text { imbalance }\end{array}$ \\
\hline Item 4 & 1 & 0.01 & 0.1 & 2 & $\begin{array}{c}\text { Severe } \\
\text { imbalance }\end{array}$ \\
\hline Item 5 & 0.359 & 0.179 & 0.253 & 3 & $\begin{array}{l}\text { Moderate } \\
\text { disorder }\end{array}$ \\
\hline Item 6 & 1 & 0.01 & 0.101 & 2 & $\begin{array}{c}\text { Severe } \\
\text { imbalance }\end{array}$ \\
\hline Item 7 & 1 & 0.01 & 0.1 & 2 & $\begin{array}{c}\text { Severe } \\
\text { imbalance }\end{array}$ \\
\hline Item 8 & 1 & 0.01 & 0.1 & 2 & $\begin{array}{c}\text { Severe } \\
\text { imbalance }\end{array}$ \\
\hline Item 9 & 0.474 & 0.097 & 0.215 & 3 & $\begin{array}{l}\text { Moderate } \\
\text { disorder }\end{array}$ \\
\hline Item 10 & 0.88 & 0.018 & 0.127 & 2 & Severe \\
\hline
\end{tabular}




\begin{tabular}{|c|c|c|c|c|c|}
\hline & & & & & imbalance \\
\hline Item 11 & 0.905 & 0.016 & 0.122 & 2 & $\begin{array}{c}\text { Severe } \\
\text { imbalance }\end{array}$ \\
\hline Item 12 & 1 & 0.01 & 0.101 & 2 & $\begin{array}{c}\text { Severe } \\
\text { imbalance }\end{array}$ \\
\hline Item 13 & 1 & 0.01 & 0.1 & 2 & $\begin{array}{c}\text { Severe } \\
\text { imbalance }\end{array}$ \\
\hline Item 14 & 1 & 0.01 & 0.101 & 2 & $\begin{array}{c}\text { Severe } \\
\text { imbalance }\end{array}$ \\
\hline Item 15 & 0.999 & 0.01 & 0.101 & 2 & $\begin{array}{c}\text { Severe } \\
\text { imbalance }\end{array}$ \\
\hline Item 16 & 1 & 0.01 & 0.1 & 2 & $\begin{array}{c}\text { Severe } \\
\text { imbalance }\end{array}$ \\
\hline Item 17 & 0.275 & 0.068 & 0.137 & 2 & $\begin{array}{c}\text { Severe } \\
\text { imbalance }\end{array}$ \\
\hline Item 18 & 0.977 & 0.946 & 0.961 & 10 & $\begin{array}{c}\text { Close } \\
\text { coordination }\end{array}$ \\
\hline Item 19 & 1 & 0.01 & 0.1 & 2 & $\begin{array}{c}\text { Severe } \\
\text { imbalance }\end{array}$ \\
\hline Item 20 & 1 & 0.01 & 0.1 & 2 & $\begin{array}{c}\text { Severe } \\
\text { imbalance }\end{array}$ \\
\hline Item 21 & 1 & 0.01 & 0.1 & 2 & $\begin{array}{c}\text { Severe } \\
\text { imbalance }\end{array}$ \\
\hline
\end{tabular}

Table 3. Coal resource reserves of China's provinces 


\begin{tabular}{|c|c|c|c|c|c|c|c|c|}
\hline $\begin{array}{l}\text { Name of } \\
\text { provinc } \\
\text { e/city/ } \\
\text { district }\end{array}$ & $\begin{array}{c}\text { Sulfur } \\
\text { dioxide } \\
\text { emissions/ } \\
10000 \\
\text { tons }\end{array}$ & $\begin{array}{c}\text { Coal } \\
\text { reserves } \\
\text { /tons }\end{array}$ & $\begin{array}{l}\text { Land } \\
\text { area/1 } \\
0000 \\
\text { square } \\
\text { kilome } \\
\text { ters }\end{array}$ & $\begin{array}{c}\text { A } \\
\text { value } \\
/ 10^{4} \\
\left(\mathrm{~km}^{2} /\right. \\
\text { a) }\end{array}$ & $\begin{array}{l}\text { Annual } \\
\text { concentr } \\
\text { ation } \\
\text { limit } C_{s} \\
\quad(\mu \\
\left.g \cdot \mathbf{m}^{-3}\right)\end{array}$ & $\begin{array}{l}\text { Average } \\
\text { annual } \\
\text { concentr } \\
\text { ation } C_{b} \\
\qquad(\mu \\
\left.g \cdot \mathbf{m}^{-3}\right)\end{array}$ & $\begin{array}{c}\text { Environ } \\
\text { mental } \\
\text { capacity/ } \\
\mathrm{SO}_{2} \\
10000 \\
\text { tons }\end{array}$ & $\begin{array}{l}\text { Atmosphe } \\
\text { ric } \\
\text { environm } \\
\text { ental } \\
\text { capacity } \\
\text { intensity(t } \\
\text { ons/a) }\end{array}$ \\
\hline Beijing & 11.50 & 3.79 & $\begin{array}{l}1.6410 \\
54\end{array}$ & 4.2 & 20 & 7.0077 & $\begin{array}{l}69.90315 \\
323\end{array}$ & Medium \\
\hline Hebei & 123.38 & 60.59 & $\begin{array}{l}18.769 \\
3\end{array}$ & 4.2 & 20 & 6.5735 & $\begin{array}{l}244.3071 \\
315\end{array}$ & Medium \\
\hline Shanxi & 124.90 & 844.01 & 15.67 & 3.5 & 20 & 7.9706 & $\begin{array}{l}166.6658 \\
067\end{array}$ & Medium \\
\hline $\begin{array}{c}\text { Inner } \\
\text { Mongoli } \\
\text { a }\end{array}$ & 139.40 & 769.86 & $\begin{array}{l}118.66 \\
5226\end{array}$ & 3.5 & 20 & 1.1747 & $\begin{array}{l}717.7474 \\
952\end{array}$ & High \\
\hline Liaoning & 91.40 & 46.63 & 14.86 & 5.6 & 20 & 6.1507 & $\begin{array}{l}298.9683 \\
776\end{array}$ & Medium \\
\hline Jilin & 35.60 & 12.40 & 18.7 & 5.6 & 20 & 1.9037 & $\begin{array}{l}438.2264 \\
812\end{array}$ & Medium \\
\hline $\begin{array}{l}\text { Heilongj } \\
\text { iang }\end{array}$ & 49.00 & 217.80 & $\begin{array}{l}45.253 \\
226\end{array}$ & 5.6 & 20 & 1.0827 & $\begin{array}{l}712.6428 \\
799\end{array}$ & High \\
\hline $\begin{array}{c}\text { Shangha } \\
\text { i }\end{array}$ & 35.80 & - & $\begin{array}{l}0.6340 \\
50\end{array}$ & 3.5 & 20 & 56.4624 & $\begin{array}{l}-101.6190 \\
309\end{array}$ & None \\
\hline Jiangsu & 105.05 & 14.23 & 10.72 & 3.5 & 20 & 9.7994 & 116.8937 & Medium \\
\hline
\end{tabular}




\begin{tabular}{|c|c|c|c|c|c|c|c|c|}
\hline & & & & & & & 133 & \\
\hline Zhejiang & 67.80 & 0.49 & 10.56 & 3.5 & 20 & 6.4205 & $\begin{array}{l}154.4485 \\
313\end{array}$ & Medium \\
\hline Anhui & 53.30 & 81.93 & $\begin{array}{l}14.013 \\
985\end{array}$ & 3.5 & 20 & 3.8033 & $\begin{array}{l}212.2146 \\
72\end{array}$ & Medium \\
\hline Fujian & 40.91 & 4.06 & 12.4 & 3.5 & 20 & 3.2992 & $\begin{array}{l}205.8335 \\
489\end{array}$ & Medium \\
\hline Jiangxi & 55.70 & 6.74 & 16.69 & 3.5 & 20 & 3.3373 & $\begin{array}{l}238.2547 \\
611\end{array}$ & Medium \\
\hline $\begin{array}{c}\text { Shandon } \\
\text { g }\end{array}$ & 154.00 & 77.56 & $\begin{array}{l}15.796 \\
5\end{array}$ & 4.2 & 20 & 9.7490 & $\begin{array}{l}171.1181 \\
041\end{array}$ & Medium \\
\hline Henan & 133.87 & 113.49 & 16.7 & 4.2 & 20 & 8.0162 & $\begin{array}{l}205.6847 \\
43\end{array}$ & Medium \\
\hline Hubei & 63.30 & 3.30 & 18.59 & 3.5 & 20 & 3.4051 & $\begin{array}{l}250.4277 \\
081\end{array}$ & Medium \\
\hline Hunan & 80.10 & 18.76 & 21.18 & 3.5 & 20 & 3.7819 & $\begin{array}{l}261.2347 \\
794\end{array}$ & Medium \\
\hline $\begin{array}{c}\text { Guangdo } \\
\text { ng }\end{array}$ & 105.50 & 1.89 & $\begin{array}{l}17.972 \\
507\end{array}$ & 3.5 & 20 & 5.8701 & $\begin{array}{l}209.6580 \\
119\end{array}$ & Medium \\
\hline Guangxi & 85.00 & 7.74 & 23.76 & 3.5 & 20 & 3.5774 & $\begin{array}{l}280.1774 \\
495\end{array}$ & Medium \\
\hline Hainan & 2.90 & 0.90 & 3.5354 & 3.5 & 20 & 0.8203 & $\begin{array}{l}126.2202 \\
782\end{array}$ & Medium \\
\hline Sichuan & 71.94 & 54.37 & $\begin{array}{l}48.605 \\
2\end{array}$ & 2.8 & 20 & 1.4801 & $\begin{array}{l}361.5247 \\
512\end{array}$ & Medium \\
\hline
\end{tabular}




\begin{tabular}{|c|c|c|c|c|c|c|c|c|}
\hline $\begin{array}{c}\text { Chongqi } \\
\text { ng }\end{array}$ & 113.10 & 22.49 & 8.24 & 1.4 & 20 & 13.7527 & $\begin{array}{l}25.10637 \\
452\end{array}$ & None \\
\hline Guizhou & 116.17 & 118.46 & 17.62 & 2.8 & 20 & 6.5931 & $\begin{array}{l}157.5757 \\
393\end{array}$ & Medium \\
\hline Yunnan & 50.07 & 62.47 & 39.41 & 2.8 & 20 & 1.2705 & $\begin{array}{l}329.2209 \\
262\end{array}$ & Medium \\
\hline Tibet & 0.39 & 0.12 & 122.84 & 7.0 & 20 & 0.0032 & $\begin{array}{l}1551.416 \\
646\end{array}$ & High \\
\hline Shaanxi & 77.90 & 119.89 & 20.56 & 2.8 & 20 & 3.7889 & $\begin{array}{l}205.8173 \\
922\end{array}$ & Medium \\
\hline Gansu & 55.20 & 58.05 & 42.58 & 2.8 & 20 & 1.2964 & $\begin{array}{l}341.7323 \\
286\end{array}$ & Medium \\
\hline Qinghai & 14.34 & 16.22 & 72.23 & 7.0 & 20 & 0.1985 & $\begin{array}{l}1178.026 \\
168\end{array}$ & High \\
\hline Ningxia & 38.30 & 54.03 & 6.64 & 3.5 & 20 & 5.76807 & $\begin{array}{l}128.3559 \\
138\end{array}$ & Medium \\
\hline Xinjiang & 58.85 & 148.31 & $\begin{array}{l}166.48 \\
97\end{array}$ & 7.0 & 20 & 0.3535 & $\begin{array}{l}1774.503 \\
736\end{array}$ & High \\
\hline Tianjing & 23.50 & 2.97 & $\begin{array}{l}1.1966 \\
45\end{array}$ & 4.2 & 20 & 19.6382 & $\begin{array}{l}1.662265 \\
986\end{array}$ & None \\
\hline
\end{tabular}

Table 4. Stability of atmospheric environment zoning

\begin{tabular}{c|c|c|c|c|c}
\hline Province, city, or & & $1 \%$ & $5 \%$ & $10 \%$ & \\
district & T statistic & critical & critical & critical & Conclusion \\
& & value & value & value & \\
\hline
\end{tabular}




\begin{tabular}{|c|c|c|c|c|c|}
\hline Beijing & -4.951 & -3.753 & -2.998 & -2.639 & Stable \\
\hline Hebei & -4.702 & -3.770 & -3.005 & -2.643 & Stable \\
\hline Shanxi & -1.690 & -3.964 & -3.085 & -2.682 & Unstable \\
\hline Inner Mongolia & -4.699 & -3.770 & -3.005 & -2.643 & Stable \\
\hline Liaoning & -4.805 & -3.753 & -2.998 & -2.639 & Stable \\
\hline Jilin & -4.483 & -3.809 & -3.022 & -2.651 & Stable \\
\hline Heilongjiang & -4.801 & -3.753 & -2.998 & -2.639 & Stable \\
\hline Jiangsu & -4.622 & -3.788 & -3.013 & -2.646 & Stable \\
\hline Zhejiang & -4.702 & -3.770 & -3.005 & -2.643 & Stable \\
\hline Anhui & -4.802 & -3.753 & -2.998 & -2.639 & Stable \\
\hline Fujian & -4.694 & -3.770 & -3.005 & -2.643 & Stable \\
\hline Jiangxi & -11.826 & -4.138 & -3.155 & -2.714 & Stable \\
\hline Shandong & -4.595 & -3.788 & -3.013 & -2.646 & Stable \\
\hline Henan & -4.805 & -3.753 & -2.998 & -2.639 & Stable \\
\hline Hubei & -1.499 & -4.138 & -3.155 & -2.714 & Unstable \\
\hline Hunan & -1.144 & -3.964 & -3.085 & -2.682 & Stable \\
\hline Guangdong & -1.695 & -4.138 & -3.155 & -2.714 & Unstable \\
\hline Guangxi & -0.644 & -4.012 & -3.104 & -2.691 & Unstable \\
\hline Hainan & -1.144 & -3.964 & -3.085 & -2.682 & Unstable \\
\hline Sichuan & -12.882 & -4.138 & -3.155 & -2.714 & Stable \\
\hline Chongqing & -4.713 & -3.770 & -3.005 & -2.643 & Stable \\
\hline Guizhou & -1.985 & -4.138 & -3.155 & -2.714 & Unstable \\
\hline Yunnan & -2.244 & -4.138 & -3.155 & -2.714 & Unstable \\
\hline Tibet & -3.772 & -3.809 & -3.022 & -2.651 & Stable \\
\hline Shaanxi & -4.805 & -3.753 & -2.998 & -2.639 & Stable \\
\hline
\end{tabular}




\begin{tabular}{c|l|l|l|l|l}
\hline Gansu & -4.811 & -3.753 & -2.998 & -2.639 & Stable \\
\hline Qinghai & -1.733 & -4.069 & -3.127 & -2.702 & Unstable \\
\hline Ningxia & -4.872 & -3.788 & -3.013 & -2.646 & Stable \\
\hline Xinjiang & -4.794 & -3.753 & -2.998 & -2.639 & Stable \\
\hline Tianjin & -5.230 & -3.753 & -2.998 & -2.639 & Stable \\
\hline Shandong & -4.595 & -3.788 & -3.013 & -2.646 & Stable \\
\hline Shanghai & -5.352 & -3.738 & -2.992 & -2.636 & Stable \\
\hline
\end{tabular}

Table 5. Arima suitability of ecological environment carrying capacity

\begin{tabular}{|c|c|c|c|c|}
\hline Province, city, or district & Coefficient & $\begin{array}{c}\text { Standard } \\
\text { error }\end{array}$ & $\begin{array}{c}\mathbf{P} \\
\text { value }\end{array}$ & Relevance \\
\hline Beijing & 0.055 & 0.041 & 0.181 & No autocorrelation \\
\hline Hebei & 0.045 & 0.042 & 0.294 & No autocorrelation \\
\hline Shanxi & 0.046 & 0.042 & 0.282 & No autocorrelation \\
\hline Inner Mongolia & 0.044 & 0.042 & 0.295 & No autocorrelation \\
\hline Liaoning & 0.043 & 0.041 & 0.294 & No autocorrelation \\
\hline Jilin & 0.049 & 0.046 & 0.287 & No autocorrelation \\
\hline Heilongjiang & 0.043 & 0.041 & 0.296 & No autocorrelation \\
\hline Jiangsu & 0.049 & 0.044 & 0.266 & No autocorrelation \\
\hline Zhejiang & 0.045 & 0.042 & 0.289 & No autocorrelation \\
\hline Anhui & 0.043 & 0.041 & 0.297 & No autocorrelation \\
\hline Fujian & 0.044 & 0.042 & 0.296 & No autocorrelation \\
\hline Jiangxi & 0.046 & 0.044 & 0.298 & No autocorrelation \\
\hline Shandong & 0.047 & 0.044 & 0.292 & No autocorrelation \\
\hline
\end{tabular}




\begin{tabular}{|c|c|c|c|c|}
\hline Henan & 0.043 & 0.041 & 0.296 & No autocorrelation \\
\hline Hubei & 0.047 & 0.044 & 0.289 & No autocorrelation \\
\hline Hunan & 0.046 & 0.044 & 0.301 & No autocorrelation \\
\hline Guangdong & 0.046 & 0.044 & 0.298 & No autocorrelation \\
\hline Guangxi & 0.044 & 0.043 & 0.302 & No autocorrelation \\
\hline Hainan & 0.045 & 0.042 & 0.286 & No autocorrelation \\
\hline Sichuan & 0.046 & 0.044 & 0.301 & No autocorrelation \\
\hline Chongqing & 0.046 & 0.042 & 0.273 & No autocorrelation \\
\hline Guizhou & 0.046 & 0.044 & 0.298 & No autocorrelation \\
\hline Yunnan & 0.048 & 0.046 & 0.299 & No autocorrelation \\
\hline Tibet & 0.070 & 0.047 & 0.136 & No autocorrelation \\
\hline Shaanxi & 0.043 & 0.041 & 0.293 & No autocorrelation \\
\hline Gansu & 0.044 & 0.041 & 0.284 & No autocorrelation \\
\hline Qinghai & 0.103 & 0.048 & 0.031 & No autocorrelation \\
\hline Ningxia & 0.071 & 0.045 & 0.118 & No autocorrelation \\
\hline Xinjiang & 0.045 & 0.041 & 0.265 & No autocorrelation \\
\hline Tianjin & 0.094 & 0.052 & 0.072 & No autocorrelation \\
\hline Shandong & 0.047 & 0.044 & 0.292 & No autocorrelation \\
\hline Shanghai & 0.091 & 0.051 & 0.072 & No autocorrelation \\
\hline
\end{tabular}

Table 6. Partition and control requirements of coal-fired power plants in China

\begin{tabular}{c|l|l}
\hline Partition & Range(province/city/district) & \multicolumn{2}{|c}{ Key points of environmental control } \\
\hline Encourage & Inner Mongolia, & This kind of area has a large relative \\
\hline
\end{tabular}




\begin{tabular}{|c|c|c|}
\hline development & Heilongjiang and Xinjiang & $\begin{array}{l}\text { atmospheric environmental capacity and } \\
\text { abundant coal reserves. Therefore, it is } \\
\text { necessary to vigorously develop modern } \\
\text { large-scale coal power bases focusing on power } \\
\text { transmission and capable of generating up to } 10 \\
\text { million kilowatts of energy. The development } \\
\text { capacity of coal power units is determined } \\
\text { according to the demand of eastern power } \\
\text { receiving areas and the national coal } \\
\text { consumption quota. In contrast, the layout of } \\
\text { new coal power supply points is determined } \\
\text { according to the regional environmental impact } \\
\text { assessment results. }\end{array}$ \\
\hline $\begin{array}{c}\text { Optimize } \\
\text { development } \\
\text { zone }\end{array}$ & $\begin{array}{l}\text { Beijing, Hebei, } \\
\text { Shanxi, Liaoning, } \\
\text { Jilin, Jiangsu, } \\
\text { Zhejiang, Anhui, } \\
\text { Fujian, Jiangxi, } \\
\text { Shandong, Henan, } \\
\text { Hubei, Hunan, Guangdong, } \\
\text { Guangxi, Hainan, Sichuan, } \\
\text { Guizhou, Yunnan, } \\
\text { Shaanxi, Gansu and Ningxia }\end{array}$ & $\begin{array}{l}\text { There is still a certain environmental capacity in } \\
\text { such areas, but the overall distribution is } \\
\text { uneven. The supporting coal-fired thermal } \\
\text { power supply mainly used in this area can be } \\
\text { moderately increased. The focus should be on } \\
\text { constructing large capacity and high parameter } \\
\text { ultra-supercritical units with a single unit of } \\
600 \text { MW or above. The emission stress of air } \\
\text { pollutants from new power plants must be } \\
\text { regulated to meet the standard of gas-fired } \\
\text { power plants. The layout of new coal power } \\
\text { supply points should be determined strictly }\end{array}$ \\
\hline
\end{tabular}


according to the regional EIA results.

In such areas, air pollution is serious, and there

is basically no environmental capacity. New coal-fired power sources are no longer planned, and new coal-fired power units are prohibited. According to the regional environmental impact assessment results, the existing site should be

\begin{tabular}{|c|c|c|}
\hline $\begin{array}{l}\text { development } \\
\text { zone }\end{array}$ & $\begin{array}{l}\text { Shanghai, Chongqing and } \\
\text { Tianjin }\end{array}$ & $\begin{array}{l}\text { used for reconstruction and expansion, and the } \\
\text { coal should be replaced by an equal or reduced } \\
\text { amount. The replaced coal should include } \\
\text { non-electric coal consumption, and the } \\
\text { self-provided coal-fired power plants should be } \\
\text { phased out. The air pollutant emissions of the } \\
\text { existing } 300000 \text { kW units and the } \\
\text { reconstruction and expansion units must meet } \\
\text { the standards of gas-fired power plants. }\end{array}$ \\
\hline
\end{tabular}

